\title{
TNFRSF18 wt Allele
}

National Cancer Institute

\section{Source}

National Cancer Institute. TNFRSF18 wt Allele. NCI Thesaurus. Code C105567.

Human TNFRSF18 wild-type allele is located in the vicinity of 1 p36.3 and is approximately $3 \mathrm{~kb}$ in length. This allele, which encodes tumor necrosis factor receptor superfamily member 18 protein, plays a role in dominant immunological self-tolerance and may play a role in both $\mathrm{T}$-cell activation and $\mathrm{T}$-cell programmed cell death. 